Shushman I, Kolesnyk P, Schonmann Y, Harris M, Frese T. Training family doctors and primary care nurses in evidence-based prevention, screening and management of cardiovascular risks in Western Ukraine: a longitudinal study. Zdr Varst. 2020;59(4):227-235. doi: 10.2478/sjph-2020-0029.

\title{
TRAINING FAMILY DOCTORS AND PRIMARY CARE NURSES IN EVIDENCE- BASED PREVENTION, SCREENING AND MANAGEMENT OF CARDIOVASCULAR RISKS IN WESTERN UKRAINE: A LONGITUDINAL STUDY \\ USPOSABLJANJE SPECIALISTOV DRUŽINSKE MEDICINE IN MEDICINSKIH SESTER V OSNOVNEM ZDRAVSTVENEM VARSTVU ZA PREVENTIVO, KI TEMELJI NA DOKAZIH, PRESEJANJE IN OBVLADOVANJE KARDIOVASKULARNIH TVEGANJ V ZAHODNI UKRAJINI: LONGITUDINALNA ŠTUDIJA
}

\author{
Ivanna SHUSHMAN ${ }^{1 *}$, Pavlo KOLESNYK ${ }^{1}$, Yochai SCHONMANN ${ }^{2,3}$, Michael HARRIS ${ }^{4,5}$, Thomas FRESE \\ ${ }^{1}$ Uzhhorod National University, Medical Faculty 2, Sobranetska Street 148, 88000 Uzhhorod, Ukraine \\ ${ }^{2}$ Department of Quality Measurements and Research, Clalit Health Services, Tel Aviv, Israel \\ ${ }^{3}$ Siaal Research Center for Family Medicine and Primary Care, Faculty of Health Sciences, \\ Ben-Gurion University of the Negev, Beer-Sheva, Israel \\ ${ }^{4}$ Shupyk National Academy of Postgraduate Education, Kyiv, Ukraine \\ ${ }^{5}$ Institute of Primary Health Care Bern (BIHAM), University of Bern, Bern, Switzerland. \\ ${ }^{6}$ Institute of General Practice and Family Medicine, Medical Faculty, \\ Martin Luther-University Halle-Wittenberg, 06112 Halle / Saale, Germany
}

\section{ABSTRACT}

Keywords:

continuing medical education, readiness to change practice, motivation, screening
Introduction: The Ukrainian primary healthcare programme of preventive and screening recommendations has not been evidence-based. The traditional system of continuous medical education in Ukraine places participants in the role of passive listeners. This study explored the effects of an interactive training course on evidence-based prevention and screening of cardiovascular risks, on changes in Ukrainian family doctors' (FDs) and primary care nurses' (PCNs) knowledge and readiness to change practice over time.

Methods: Three hundred and seven FDs and PCNs participated in the study. Changes in participants' knowledge were assessed with 20 multiple choice questions, and their readiness to change practice with a five-item questionnaire. These were administered before, immediately after, three and twelve months after training.

Results: The mean pre-course knowledge score was 6.1 (SD 1.8) out of 20, increasing to 14.9 (SD 2.3) immediately afterwards $(p<0.001)$. Three months later it was 10.2 (SD 3.2) and at one year it was 10.4 (SD 3.3), both of which were significantly higher than the pre-training level $(p<0.005)$. The percentage of participants that were highly motivated to change their practice increased from $18.4 \%$ before the training to $62.3 \%$ immediately afterwards $(\mathrm{p}<0.001)$. Three months later, this fell to $40.4 \%$. At 12 months it further reduced to $27.4 \%$, but was still significantly higher than the baseline level $(\mathrm{p}<0.001)$.

Conclusions: The interactive training was effective in increasing both participants' knowledge and their readiness to change their clinical practice. The impact of the training diminished over time, but was still evident a year later.

\section{IZVLEČEK}

Ključne besede: stalno medicinsko izobraževanje, pripravljenost na spremembo prakse, motivacija, presejanje
Uvod: Ukrajinski program osnovnega zdravstvenega varstva s priporočili za preventivo in presejanje ni temeljil na dokazih. Tradicionalni sistem stalnega medicinskega izobraževanja v Ukrajini postavlja udeležence $v$ vlogo pasivnih poslušalcev. $V$ tej študiji so preučili učinek interaktivnega tečaja usposabljanja za preventivo, temelječo na dokazih, in presejanje kardiovaskularnih tveganj na spremembe $v$ znanju ukrajinskih družinskih zdravnikov in medicinskih sester v osnovnem zdravstvenem varstvu ter na njihovo pripravljenost, da sčasoma spremenijo prakso.

Metode: $V$ študiji je sodelovalo 307 družinskih zdravnikov in medicinskih sester $v$ osnovnem zdravstvenem varstvu. Spremembe $v$ znanju udeležencev so ocenili z 20 vprašanji izbirnega tipa, njihovo pripravljenost za spremembo prakse pa z vprašalnikom s 5 točkami. Ta vprašanja/vprašalnike je bilo treba izpolniti pred usposabljanjem, takoj po njem ter čez 3 in 12 mesecev.

Rezultati: Povprečna ocena znanja pred tečajem je bila 6,1 (SD 1,8) od 20, takoj po tečaju pa se je povečala na 14,9 (SD 2,3; $p<0,001)$. Čez 3 mesece je bila ocena 10,2 (SD 3,2) in po enem letu 10,4 (SD 3,3), kar je v obeh primerih pomembno višje od ravni pred usposabljanjem $(p<0,005)$. Odstotek udeležencev, ki so bili zelo motivirani za spremembo prakse, se je z 18,4\% pred usposabljanjem povečal na $62,3 \%$ takoj po usposabljanju $(p<0,001)$. V 3 mesecih se je ta delež zmanjšal na 40,4\%. Po 12 mesecih se je dalje zmanjšal na 27,4 \%, vendar je bil še vedno pomembno višji od izhodiščne ravni $(p<0,001)$.

Sklepi: Interaktivno usposabljanje je učinkovito povečalo tako znanje udeležencev kot njihovo pripravljenost za spremembo klinične prakse. Učinek usposabljanja se je sčasoma zmanjšal, vendar je bil po enem letu še vedno očiten.

\footnotetext{
*Corresponding author: Tel. + 380999184 450; E-mail: ivshushman@gmail.com
} 


\section{INTRODUCTION}

The global burden of chronic non-communicable diseases is rising, and achieving an adequate balance between addressing modifiable risk factors and avoiding overtreatment is a international priority (1-3). In the past, chronic disease screening systems in post-Soviet countries were not evidence-based (4). Following Ukrainian Ministry of Health Care legislation in 2018, the post-Soviet screening protocol was cancelled (5), and it has not been replaced by a new state screening system (4). Individual primary care providers (mainly family doctors, FDs) have their own systems of screening for their patients, which are not always evidence-based, but there are now plans for a state cardio-vascular risk screening programme (blood pressure, cholesterol and blood glucose measurements, body mass index evaluation) (4). The future role of primary care nurses (PCNs) in screening for chronic disease in Ukraine is, as yet, undecided (4), but there is a move to involve them in screening management. There is, therefore, a need to increase the knowledge of both FDs and PCNs regarding evidence-based screening recommendations and to increase their readiness to implement them (4).

Continuing medical education (CME) increases clinician knowledge, as well as improving their performance and patient outcomes (6). The effect size is larger when the educational interventions are interactive (7) and use multiple methods (6). Traditional lectures and seminars are less effective than interactive teaching $(8,9)$, yet passive learning with minimal trainee participation still dominates the medical education curriculum in Ukraine and other post-Soviet Eastern European countries (10-12). Innovative training techniques may thus improve FD and PCN training in these countries and be an effective means to induce changes in medical practice $(13,14)$. Interactive teaching techniques are recommended by the European Academy of Teachers in General Practice / Family Medicine (EURACT) and other medical organizations, and are part of the blended teaching model used with FDs in most developed European countries (15-17). Interactive training seminars combine various methods which draw participants' attention and involve them in practical interactions (18-21). Interactive pedagogical methods include "brainstorming" (a group activity that encourages participants to focus on a topic and contribute to the free flow of ideas), work in small groups, demonstrations, presentation of clinical cases, role-play and feedback. Active teaching/learning techniques can be used to develop creative thinking and establish practical skills and competencies $(8,22,23)$. Interactive methods of education in CME of doctors and nurses, such as blended learning, may help to raise their levels of knowledge (15, 17). While interactive training, with the assessment of FDs' knowledge levels before and immediately after the training, is being introduced into the system of education for primary health care providers in different regions of Ukraine, it mostly relates to emergency care $(24,25)$.

We aimed to evaluate the effectiveness of interactive training sessions for FDs and PCNs on evidence-based prevention screening and management of cardiovascular risks. We describe our experience in introducing such a training programme in the western (Transcarpathian) region of Ukraine, and we report the changes in participants' level of knowledge and their readiness to implement the evidence-based strategies they learned over time.

\section{METHODS}

\subsection{Setting}

The Transcarpathian region is a mountainous area of western Ukraine which includes some remote and distant districts. Primary medical health care is provided by 662 FDs and by approximately 1,000 PCNs for the region's population of 1.25 million people, about two-thirds of whom live rurally. All FDs and PCNs work at statesupported family medicine clinics, subordinated to local Primary Care Centres.

CME, in the form of a one-month academic course every five years, has been mandatory for FDs and PCNs wishing to confirm or upgrade their qualification category. These courses are conducted at the Postgraduate Faculty of the Uzhhorod National University (UzhNU), and are funded by the practitioners themselves, or by their Primary Care Centres (10). The courses have mainly been based on traditional didactic lectures, with the teaching provided by non-FD specialists. FDs from remote districts often work in solo practices without replacements available and thus cannot complete the full one-month training course. Shorter practical training sessions can, therefore, potentially become an alternative to the current system.

\subsection{The Training Sessions}

Our team at the UzhNU Family Medicine Training Centre organized an eight-hour practical training course on "Evidence-based steps for the prevention, screening and management of cardiovascular risks in FD's practice". We used a blended model of teaching with interactive pedagogical techniques that were developed from descriptions of similar programmes in other countries (22, 23). We held 20 identical training sessions for FDs and PCNs in the 12 districts of the Transcarpathian region during 2016-2017, and each participating FD and PCN attended a single session. PCNs were invited to the sessions to increase their understanding of their role in screening management, as we considered that they could be involved in counselling at-risk patients (smoking cessation, lifestyle changes, etc.), measurement of body mass index (BMI) and blood pressure (BP), glucose and cholesterol testing, and organizing follow-up appointments. 
At the beginning of each training session we gave a short interactive introductory talk, aimed at increasing participants' readiness to implement changes in their medical practice. To allow for multiple points of view, we then divided the participants into five small groups (usually with six participants in each). To ensure that each group could benefit from a wide range of skills and experience, the groups were made heterogeneous in terms of age, profession (FD/PCN) and experience. Trainers from our training centre (members of EURACT who were trained in, and had experience of, using interactive training methods for FDs) facilitated a series of four 45-minute workshops, leading discussions on the prevention, screening and management of cardiovascular diseases. The trainers encouraged the participants to express their thoughts and suggest solutions to perceived barriers. Every group rotated through each of the four workshops, with short breaks (5-15 minutes) in between. An overview of the modules is given in Table 1.

Table 1. Module aims and teaching methods.

\begin{tabular}{|c|c|c|}
\hline Module name & Key learning aims & Teaching methods used \\
\hline $\begin{array}{l}\text { Evidence-based approaches to } \\
\text { effective counselling for patients } \\
\text { with cardiovascular risks }\end{array}$ & $\begin{array}{l}\text { Evidence-based counselling methods } \\
\text { for patients with cardiovascular risks }\end{array}$ & $\begin{array}{l}\text { - Participant discussion of clinical cases } \\
\text { - Work in small groups } \\
\text { - Role-play }\end{array}$ \\
\hline Metabolic syndrome & $\begin{array}{l}\text { Screening and management of components } \\
\text { of metabolic syndrome }\end{array}$ & $\begin{array}{l}\text { - Brainstorming } \\
\text { - Demonstrations of practical } \\
\text { skills (determination of BMI, waist } \\
\text { circumference, glucose measurement) } \\
\text { - Clinical cases discussion } \\
\text { - Work in small groups }\end{array}$ \\
\hline Rational statin therapy & $\begin{array}{l}\text { Evidence-based steps for dyslipidemia } \\
\text { screening and rational statin therapy for } \\
\text { patients with cardiovascular risks }\end{array}$ & $\begin{array}{l}\text { - Brainstorming } \\
\text { - Hands-on training in taking blood samples } \\
\text { for lipid profile and glucose measurement } \\
\text { - Clinical cases discussion } \\
\text { - Work in small groups }\end{array}$ \\
\hline $\begin{array}{l}\text { Essential hypertension } \\
\text { and its complications }\end{array}$ & $\begin{array}{l}\text { Evidence-based steps for management } \\
\text { of patients with essential hypertension } \\
\text { and its complications }\end{array}$ & $\begin{array}{l}\text { - Brainstorming } \\
\text { - Work in small groups } \\
\text { - Participant discussion of clinical cases }\end{array}$ \\
\hline
\end{tabular}

Module 1 ("Evidence-based approaches to effective counselling for patients with cardiovascular risks") employed participant role-play. Participants were offered situational tasks, as close as possible to real life situations, which gave them the opportunity to apply their knowledge and skills regarding effective counselling of patients with cardiovascular disease risks.

Module 2 ("Metabolic syndrome") included a presentation of a simulated clinical case, with use of "brainstorming" and demonstrations of practical skills (determination of BMI, waist circumference, glucose measurement). An online resource for FDs that had been developed by the organizers, the "Primary Prevention and Screening Calculator", was presented to the participants for use in their practice (26). This resource gives practitioners clear evidence-based algorithms for the prevention of cardiovascular disease, and advice on how to develop a cardiovascular disease screening plan.

Module 3 ("Rational statin therapy") was conducted as a clinical case demonstration of evidence-based management of a patient with dyslipidemia in an FD's practice. During this session the PCNs had an opportunity to get hands-on training in taking blood samples for lipid profile and glucose measurement.

Module 4 (“Essential hypertension and its complications") was the final session, in which all participants brainstormed techniques and discussed clinical cases. 


\subsection{Questionnaires}

Participants completed two paper questionnaires in which they were asked to state their age, profession (FD or PCN), number of years in practice, and location of their practice (rural or urban). We assessed participants' knowledge levels by using 20 multiple choice questions (MCQs) about the training topic, chosen by the course trainers from a bank of MCQs used for the certification of doctors and nurses (31). Each correctly answered question was given a score of 1 point, and a wrong answer scored no points, giving a possible range of $0-20$ points. We categorized the results as 'high' or 'low' levels of knowledge, depending on whether individuals answered more than half of the questions correctly ( $\geq 11$ points).

We assessed participants' readiness to implement evidence-based prevention and screening with a five-item questionnaire (see Appendix 1). The items were adapted from an IDEA Health and Fitness Association questionnaire (27) and piloted by 20 FDs and 20 PCNs. No changes needed to be made as a result of the pilot. Respondents were asked to assess their levels of readiness to use evidencebased screening of cardio-vascular risks in their own clinical practice, using a five-point scale (ranging from 1, not ready/unmotivated, to 5 , very ready/motivated). For each respondent, the sum of the five scores gave a total "readiness to change" score, giving a possible range of 5 to 25 . Scores of $\geq 21$ were categorized as "Very ready to change practice".

We administered the questionnaires immediately before and after the training, as well as three months and one year after the training days. For the latter, we emailed the questionnaires to each of the regional departmental heads, who sent paper copies to the practitioners in their regions. The completed questionnaires were returned to us by post.

\subsection{Statistical Analysis}

Participants' baseline characteristics were analysed using percentages for categorical variables, with means and standard deviations (SD) for continuous variables. The scores for each round of questionnaires and the proportion of those who achieved high scores are presented as means with $95 \%$ confidence intervals $(\mathrm{Cl})$. Chi square tests were used to compare proportions, and t-tests to compare means. Statistical data were processed using Stata, version 15.1 IC (StataCorp LP, College Station, Texas).

\section{RESULTS}

Overall, 600 FDs and PCNs took part in the training sessions, and of those 307 (51.2\%) (211 FDs, 96 PCNs) agreed to participate in the study. All study participants completed the survey immediately after and three months after the training, but 12 months afterwards only 218 participants out of the $307(71 \%)$ did so. The mean study participant age was 45.4 years (SD 12.8), and most (73.4\%) worked in rural areas (Table 2).

Table 2. Characteristics of study population $(\mathrm{N}=307)$.

\begin{tabular}{lc}
\hline Mean age (SD) & $45.4(12.8)$ \\
Age $<45$ years (\%) & $146(47.6)$ \\
Profession (\%) & \\
Primary care nurse & $96(31.3)$ \\
Family doctor & $211(68.7)$ \\
Years in practice (\%) & \\
$<10$ & $59(19.1)$ \\
$10-19$ & $48(15.7)$ \\
$20-29$ & $85(27.8)$ \\
$\geq 30$ & $115(37.4)$ \\
Working in rural practices (\%) & $225(73.4)$ \\
\hline
\end{tabular}

The mean participant knowledge level before the training was 6.1 (SD 1.8) (see Figure 1 and Table 3), and significantly higher immediately after the training: 14.9 (SD 2.3, $p<0.001)$. Three months after the training it was 10.2 (SD 3.2), and one year after the training it was 10.4 (SD 3.3), both of which were significantly higher than the pre-training level $(p<0.005)$.

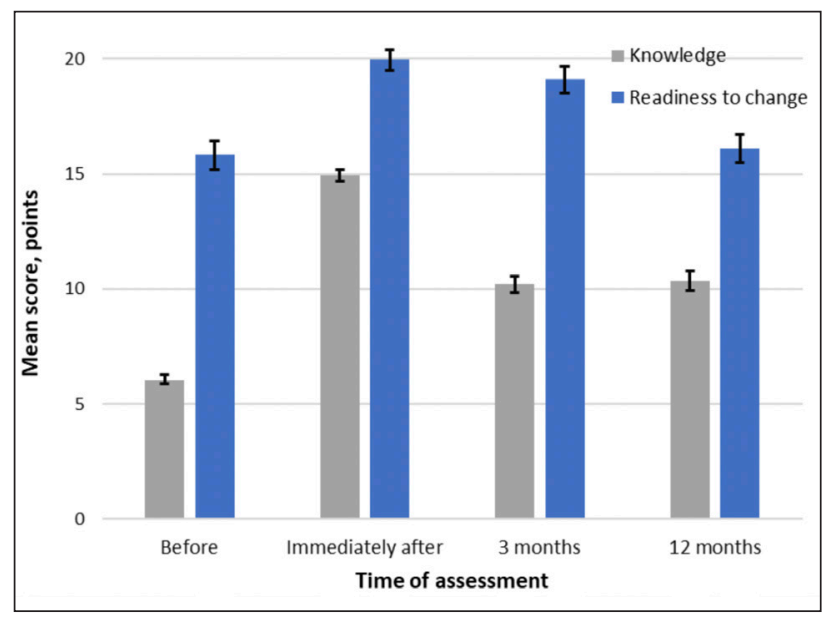

Figure 1. Mean participant knowledge and levels of readiness to change at different times, with $95 \%$ confidence intervals. 
The mean level of readiness to implement evidence-based prevention, screening and management of cardiovascular risks at the beginning of the training was 15.8 (SD 3.4) (see Figure1 and Table 3). Immediately after the training, it increased to 20.0 (SD 2.4), significantly higher than the pre-course results $(p<0.005)$. While three months after the training this increase had been maintained, at 19.1 (SD 3.2), and was still significantly higher than before the training, twelve months after the training it had fallen to 16.1 (SD 4.5), similar to the pre-training level.

Table 3. Results of the knowledge and readiness to change questionnaires before and after the training sessions.

\begin{tabular}{|c|c|c|c|c|}
\hline \multirow[b]{2}{*}{ Characteristic } & \multicolumn{2}{|c|}{ Knowledge } & \multicolumn{2}{|c|}{ Readiness to change } \\
\hline & Mean score (SD) & $\begin{array}{c}\text { High level of knowledge, } \\
\%(95 \% \mathrm{Cl})\end{array}$ & Mean score (SD) & $\begin{array}{l}\text { High level of motivation, } \\
\qquad \%(95 \% \mathrm{Cl})\end{array}$ \\
\hline Before training & $6.1(1.8)$ & $2.4(1.0-4.7)$ & $15.8(3.4)$ & $18.4(11.8-26.7)$ \\
\hline Immediately after training & $14.9(2.3)$ & $93.7(90.5-96.1)$ & $20.0(2.4)$ & $62.3(52.7-71.2)$ \\
\hline After 3 months & $10.2(3.2)$ & $51.7(46.1-57.1)$ & $19.1(3.2)$ & $40.4(31.3-50.0)$ \\
\hline After 12 months & $10.4(3.3)$ & $48.2(41.4-55.1)$ & $16.1(4.5)$ & $27.4(21.6-33.8)$ \\
\hline
\end{tabular}

The proportion of FDs and PCNs who had a high level of knowledge ( $\geq 11$ points) before the training was $2.4 \%$, immediately after the training it was $93.7 \%$, three months after the training it was $51.7 \%$, and after 12 months it was $48.2 \%$. All these values were significantly higher than that for the pre-training course $(p<0.001)$, (Figure 2$)$.

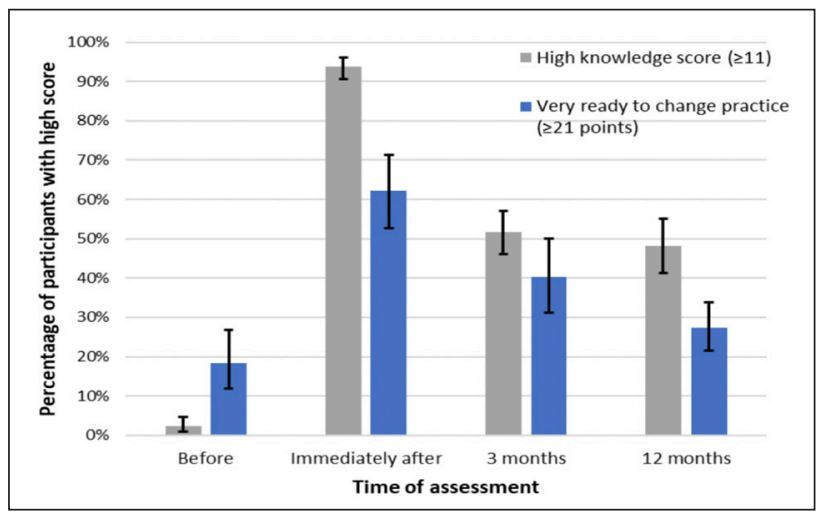

Figure 2. Percentage of participants who answered more than half of the questions correctly at different times, and who were very ready to make changes to their practice, with $95 \%$ confidence intervals.

The percentage of FDs and PCNs that were very ready to implement evidence-based preventive measures in their own practices increased significantly from $18.4 \%$ before the training to $62.3 \%$ immediately after $(\mathrm{p}<0.001)$ (see Figure 2 and Table 3). Three months later, this had fallen to $40.4 \%$, and after 12 months it had further reduced to $27.4 \%$, though this was still significantly higher than the pre-training level $(p<0.001)$.

\section{DISCUSSION}

\subsection{Summary of Important Findings}

In a training programme for FDs and PCNs in western Ukraine, the level of knowledge of evidence-based prevention, screening and management of cardiovascular risks increased substantially after a one-day interactive training course and, while it reduced in subsequent testing, remained significantly higher than baseline one year later. While the percentage of participants who were very ready to make changes to their clinical practice was significantly higher at all stages after the training, overall readiness-to-change scores had fallen back to nearbaseline levels one year later.

\subsection{Strengths and Limitations}

This is the first report of interactive training for FDs and primary care nurses in this region. The study included almost a third of all the FDs working in the Transcarpathian region. We were able to explore the effects of our training programme over twelve months of follow-up. While just over half of the training session participants completed the questionnaires, we did not have consent to collect data on the characteristics of those that did not complete these. The knowledge level questions were chosen by experienced FDs from a pre-existing MCQ question bank and therefore have face validity. The "readiness to change" questionnaire was piloted before use in the study. However, we did not assess the reliability of either questionnaire.

We also did not assess whether the programme had an impact on actual patient care. There was no comparison 
of the effect of the interactive training seminars with traditional Ukrainian medical teaching methods, such as didactic lectures. Moreover, it should be noted that other, unmeasured factors could have influenced participants' knowledge and readiness to change during the year following their training seminars.

\subsection{Comparison with Existing Literature}

A Spanish study assessed the effect of an interactive course comprising four half-day sessions designed to develop the knowledge and skills required to practice evidence-based care (22). Similar to our study, it demonstrated a significant increase in participants' knowledge. However, there was no follow-up beyond the questionnaire administered at the end of the course. In a study in China, a weekly face-to-face evidence-based medicine training course was found to increase knowledge and future anticipated use (24). Participants' subsequent management of hypertension in the community was significantly better than that of a control group that had followed a self-instruction course instead. In a South African five-day interactive training programme for family physician clinical trainers, participants showed an increase in self-reported competencies three months after the course, but an objective assessment showed no change in their capabilities (25).

In a manual for motivational interview training, there are recommendations to assess participants' levels of interest and confidence in their skills, their readiness to learn those skills, and their self-perceived skill levels (26), all of which were assessed in our interactive training programme. The majority of General Practitioners (GPs) consider evidencebased medicine to be a positive concept (32). However, barriers have been reported that limit its use $(33,34)$. Research showed that audits, feedback information and group discussion positively contributed to Dutch GPs' motivation to change their practice (35).

\subsection{Interpretation of the Findings and Recommendation for Further Research}

An interactive teaching method for Ukrainian primary care clinicians resulted in an increase in their knowledge and readiness to change clinical practice, which was to a varying extent still present a year later. Barriers to changing practice identified by the participants included lack of time for motivational interviewing, low levels of patient motivation for lifestyle modification and limited access to screening investigations, especially in rural areas, and these may have limited the extent to which the participants' own motivation increased.

While there was an immediate increase in the levels of motivation, this reduced over time, which may reflect the limited effect of the single, eight-hour intervention.
More research is thus needed to find out whether the increased readiness to change results in real changes in clinical practice, and, if so, what those changes are. There is also a need to find out how, in the post-Soviet Eastern European countries, the increased readiness to change clinical practice can be sustained in the long term.

\section{CONCLUSIONS}

Interactive training is an effective way to increase primary care clinicians' level of knowledge of evidencebased prevention, screening and management of their patients' cardiovascular disease risks, and their short-term readiness to make changes. Although participants' level of knowledge increased and remained stable between three and 12 months after training, their initial increase in levels of readiness to change reduced over that time. Further research should thus identify methods to attain longlasting effects from CME, as well as explore the effects of this course on practitioners' satisfaction and patients' health outcomes.

\section{ACKNOWLEDGMENTS}

We would like to thank the participants who took part in this study, the Regional Health Care Department of Transcarpathian Regional Administration in support of training, the Postgraduate Faculty of UzhNU for the use of their teaching facilities, the trainers of the Family Medicine Training Centre of Postgraduate Faculty, and the doctors and nurses who piloted the survey.

\section{FUNDING}

The training was supported by the Regional Health Care Department of Transcarpathian Regional Administration, which helped reimburse the participants' expenses. The Regional Health Care Centres and Uzhgorod University paid the trainers' salaries.

\section{COMPETING INTERESTS}

The authors declare no conflicts of interest.

\section{ETHICS APPROVAL}

Research ethics approval was not required as no biomedical intervention was performed. 


\section{REFERENCES}

1. GBD 2017 Disease and Injury Incidence and Prevalence Collaborators. Global, regional, and national incidence, prevalence, and years lived with disability for 354 diseases and injuries for 195 countries and territories, 1990-2017: a systematic analysis for the Global Burden of Disease Study 2017. Lancet. 2018; 392:1789-858. doi: 10.1016/S0140-6736(18)32279-7.

2. GBD 2016 Russia Collaborators. The burden of disease in Russia from 1980 to 2016: a systematic analysis for the Global Burden of Disease Study 2016. Lancet. 2018;392:1138-46. doi: 10.1016/S0140-6736(18)31485-5.

3. Moynihan R, Doust J, Henry D. Preventing overdiagnosis: how to stop harming the healthy. BMJ. 2012;344. doi: 10.1136/bmj.e3502.

4. Kolesnyk P, Matyukha L, Kolesnyk A, Niroda A, Shushman I, Zharkova A. Moving from "tradition" based screening to evidence base screening in Ukraine - challenges and how to meet them. In: International Conference of Family Doctors, "PiFy 2020". Tel Aviv, 2020: P.4.

5. Order of the Ministry of Health of Ukraine dated March 19, 2018 № 504. "On approval of the Procedure for providing primary care". Accessed March 19th, 2018 at: https://moz.gov.ua/article/ministry-mandates/nakazmoz-ukraini-vid-19032018--504-pro-zatverdzhennjaporjadku-nadannja-pervinnoi-medichnoi-dopomogi.

6. Mansouri M, Lockyer J. A meta-analysis of continuing medical education effectiveness. J Contin Educ Health Prof. 2007;27(1):6-15. doi: 10.1002/chp.88.

7. Davis D, O'Brien MA, Freemantle N, Wolf FM, Mazmanian $P$, Taylor-Vaisey A. Impact of formal continuing medical education: do conferences, workshops, rounds, and other traditional continuing education activities change physician behavior or health care outcomes? JAMA. 1999;282(9):867-74. doi: 10.1001/jama.282.9.867.

8. Meguid EA, Collins M. Students' perceptions of lecturing approaches: traditional versus interactive teaching. Adv Med Educ Pract. 2017;8:229-41. doi: 10.2147/AMEP. S131851.

9. Miller CJ, McNear J, Metz MJ. A comparison of traditional and engaging lecture methods in a large, professionallevel course. Adv Physiol Educ. 2013;37(4):347-55. doi: 10.1152/advan.00050.2013.

10. Kolesnyk P, Švab I. Development of family medicine in Ukraine. Eur J Gen Pract. 2013;19(4):261-5. doi: 10.3109/13814788.2013.807791.

11. Brekke M, Carelli F, Zarbailov N, Javashvili G, et al. Undergraduate medical education in general practice/ family medicine throughout Europe - a descriptive study. BMC Med Educ. 2013;13:157. doi: 10.1186/14726920-13-157.
12. Krztoń-Królewiecka A., Švab I, Oleszczyk M, Seifert B, et al. The development of academic family medicine in central and eastern Europe since 1990. BMC Fam Pract. 2013;14:37. doi: 10.1186/1471-2296-14-37.

13. Shushman I, Kolesnyk P, Kenez Y. What is more sustainable late after family doctor's training: academic knowledge or motivation to change the performance? In: EURACT Medical Education Conference. Leuven, 2018.

14. Sinclair P, Kable A, Levett-Jones T. The effectiveness of internet-based e-learning on clinician behavior and patient outcomes: a systematic review protocol. JBI Database System Rev Implement Rep. 2015;13(1):52-64. doi: 10.11124/jbisrir-2015-1919.

15. Bednář J, Andreeva E, Homar V, Kalda R, Kiknadze N, Kolesnyk P. Developing effective Continuing Medical Education [CME] for isolated family doctors. In: EURACT Medical Education Conference. Leuven, 2018.

16. Ristovski R, Sekuloski R, Risteska Nejashmikj V, Bednár J, Kolesnyk P, et al. How to teach active listening. In: EURACT Medical Education Conference. Leuven, 2018.

17. Granek-Catarivas M, Zarbailov N, Karppinen H, Carelli F, Kiknadze N, Cojić M, et al. Blended learning material in family medicine education - now!. In: EURACT Medical Education Conference. Leuven, 2018.

18. Bleske BE, Remington TL, Wells TD, Klein KC, Tingen JM, Dorsch MP. A randomized crossover comparison between team-based learning and lecture format on long-term learning outcomes. Pharmacy (Basel). 2018;4;6. doi: 10.3390/pharmacy6030081.

19. Pal R, Kar S, Zaman FA, Jha DK, Pal S. Assessment of impact of small group teaching among students in community medicine. Indian J Community Med. 2012;37(3):170-3. doi: 10.4103/0970-0218.99920.

20. Brookfield SD, Preskill S. Discussion as a way of teaching: tools and techniques for democratic classrooms. 2nd ed. San Francisco: Jossey-Bass, 2005.

21. Ahmadi SF, Baradaran HR, Ahmadi E. Effectiveness of teaching evidence-based medicine to undergraduate medical students: a BEME systematic review. Med Teach. 2015;37(1):21-30. doi: 10.3109/0142159X.2014.971724.

22. Argimon-Pallàs JM, Flores-Mateo G, Jiménez-Villa $\mathrm{J}$, Pujol-Ribera E. Effectiveness of a short-course in improving knowledge and skills on evidence-based practice. BMC Fam Pract. 2011;12:64. doi: 10.1186/14712296-12-64.

23. Abdel-All M, Putica B, Praveen D, Abimbola S, Joshi R. Effectiveness of community health worker training programmes for cardiovascular disease management in low-income and middle-income countries: a systematic review. BMJ Open. 2017;7(11). doi: 10.1136/ bmjopen-2016-015529. 
24. Matyukha L, Malyutina N, Vasilyeva N. Simulation teaching methods - a modern direction of the development of postgraduate education in medicine. Med Emergency Cases. 2016:57-60.

25. Beketova GV, Alekseenko NV, Goryacheva IP, Soldatova OV, Nekhaenko MI. Introduction of a new method of interactive training of doctors of trainees of cycles of advanced training in the department of paediatric and adolescent diseases. In: Collection of scientific works of staff members of NMAPE. Kyiv: Shupyk National Medical Academy of Postgraduate Education, 2014:562-6.

26. Calculator of prevention and screening. Accessed March 19th, 2018 at: http://health.uzhnu.edu.ua/.

27. Mc Millan, S. Help clients get motivated. In: IDEA Health \& Fitness Association. How to motivate and retain your clients. IDEA Health \&Fitness, 2002:8-15.

28. Fei J, Li Y, Gao W, Li J. Efficacy of evidence-based medicine training for primary healthcare professionals: a non-randomized controlled trial. BMC Med Educ. 2018;18(1):299. doi: 10.1186/s12909-018-1404-y.

29. Mash R, Blitz J, Edwards J, Mowle S. Training of workplace-based clinical trainers in family medicine, South Africa: before-and-after evaluation. Afr J Prim Health Care Fam Med. 2018;10(1):1589. doi: 10.4102/ phcfm.v10i1.1589.

30. Yahne K. Readiness Ruler Lineup. In: Rogers CR., Russel $\mathrm{DE}$, et al. Motivational interviewing training new trainers manual. Roseville: Penmarin Books, 2014:18-9.

31. "Testing centre". Accessed March 19th, 2018 at: https://testcentr.org.ua/uk/krok-3.

32. McColl A, Smith H, White P, Field J. General practitioners' perceptions of the route to evidence based medicine: a questionnaire survey. BMJ. 1998;316(7128):361-5.

33. Evidence-based practice barriers and facilitators from a continuous quality improvement perspective: an integrative review. Solomons NM, Spross JA J Nurs Manag. 2011;19(1):109-20.

34. van Dijk N, Hooft L, Wieringa-de Waard M. What are the barriers to residents' practicing evidencebased medicine?: a systematic review. Acad Med. 2010;85(7):1163-70.

35. van Braak M, Visser $M$, Holtrop $M$, et al. What motivates general practitioners to change practice behaviour?: a qualitative study of audit and feedback group sessions in Dutch general practice. BMJ Open. 2019;9:e025286. doi:10.1136/ bmjopen-2018-025286. 
Appendix 1. "Readiness to change" questionnaire.

Please estimate your level of readiness to use evidencebased screening of cardio-vascular risks in your own clinical practice, using a 5-point scale (where 1 is not ready/unmotivated, 2 is slightly ready/motivated, 3 is moderately ready/motivated, 4 is well motivated/ready, 5 is very ready/motivated).

Rating, from 1 to 5

1. From a personal point of view, how motivated are you to conduct evidencebased screening of cardio-vascular risks in your own clinical practice?

2. Taking external factors into account, how motivated are you to conduct evidence-based screening of cardio-vascular risks?

3. How ready will you be to implement the planned new state programme of screening for cardio-vascular risks?

4. How ready are you, in terms of your own clinical abilities, to conduct evidence-based screening of cardio-vascular risks?

5. How ready are you to manage the full range of evidencebased screening tests for cardio-vascular risks? *

* Evidence-based screening of cardiovascular risks includes:

- every 1-2 years, measuring the blood pressure of all your patients who are aged 18 or older;

- regular assessment of cardio-vascular risk factors (smoking, alcohol intake, calculation of BMI, family history) for all your patients who are aged 18 or older;

- lipid profile measurement every 5 years, in all your male patients who are aged 40 or older, and all your female patients who are aged 45 or older;

- blood glucose measurement every 5 years for all your patients who are aged 45 or older, or sooner in patients with $\mathrm{BMI} \geq 25$ or who have additional risk factors. 